\title{
The behaviour of pyruvate dehydrogenase in circulating lymphocytes from diabetic children
}

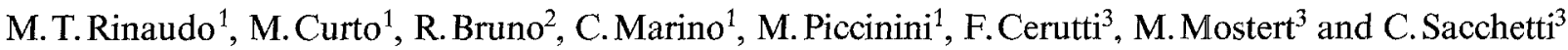 \\ ${ }^{1}$ Dipartimento di Medicina ed Oncologia Sperimentale-Sezione Biochimica, ${ }^{2}$ Dipartimento di Morfofisiologia Veterinaria, and \\ ${ }^{3}$ Istituto di Clinica Pediatrica, Università di Torino, Italy
}

Summary. The basal and total pyruvate dehydrogenase activities were assayed in circulating lymphocytes from children with juvenile diabetes at diagnosis and after five days of insulin therapy and from control subjects. In untreated diabetic children, basal and total pyruvate dehydrogenase activities were deeply decreased and both showed very similar values; whereas, in control subjects basal activity was about $30 \%$ lower than total activity. In diabetic patients treated with in- sulin (in vivo situation), both basal and total activity levels were equal or even higher than those of the control subjects. The incubation of lymphocytes from diabetic patients with insulin $(5 \mu \mathrm{U} / \mathrm{ml})$ (in vitro situation) stimulates, but less than in vivo, the basal and total pyruvate dehydrogenase activities.

Key words: Type 1 (insulin-dependent) diabetic children, lymphocytes, pyruvate dehydrogenase.
The pyruvate dehydrogenase complex, located in mitochondria, is formed by three components, one of which, called pyruvate dehydrogenase (PDH) exists in two interchangeable forms, dephosphorylated active $\left(\mathrm{PDH}_{\mathrm{a}}\right)$ and phosphorylated inactive $\left(\mathrm{PDH}_{\mathrm{i}}\right)$. Phosphorylation is catalysed by pyruvate dehydrogenase kinase, sharply bound to the complex, in the presence of ATP and $\mu \mathrm{mol} / 1 \mathrm{Mg}^{2+}$. Dephosphorylation is carried out by PDH phosphate (PDHP) phosphatase, loosely bound to the complex; the phosphatase requires, for its catalytic activity, $\mathrm{mmol} / \mathrm{I} \mathrm{Mg}^{2+}$, whose effects are almost completely nullified by $\mathrm{mmol} / \mathrm{l}$ fluoride, and $\mu \mathrm{mol} / \mathrm{l}$ $\mathrm{Ca}^{2+}$, which strengthens the phosphatase bond to the complex $[1,2]$. Therefore, the PDH activity assayed in crude preparations (homogenates, lysed cells) pre-incubated with $\mathrm{mmol} / 1 \mathrm{Mg}^{2+}$ and $\mu \mathrm{mol} / 1 \mathrm{Ca}^{2+}$ represents the total activity of the PDH complex (PDHt), sum of the activity of the previously inactive and later converted into the active PDH, and of the pre-existing active PDH (PDHa). At the same time, this assay allows the opportunity to test the amount of PDHi converted into PDHa and consequently expresses the activity level of PDHP phosphatase.

In human circulating lymphocytes from donors with normal blood glucose levels, PDHa is about $60 \%$ of PDHt, i.e. about $40 \%$ of PDH exists in the inactive phosphorylated form [2]. The ratio changes if circulating intact lymphocytes are contacted with insulin in a medium supplemented with $50 \mu \mathrm{mol} / 1 \mathrm{Ca}^{2+} \mathrm{Mg}^{2+}$. Maximum PDHi into PDHa conversion is obtained with $5 \mu \mathrm{U} / \mathrm{ml}$ insulin for a contact time of $10 \mathrm{~min}$ at $\mathrm{pH} 7.4$ and at $37^{\circ} \mathrm{C}$. Furthermore, a cell free prepara- tion from circulating lymphocytes, incubated with insulin in the above described conditions, retains the ability to modify the PDH behaviour when combined with intact or lysed circulating lymphocytes [2]. Therefore, in vitro insulin seems to modulate the PDH behaviour in human circulating lymphocytes not through a direct interaction with the PDH complex, but through a substance(s) generated at the plasma membrane level which enters the cell and contacts mitochondria. This mechanism has also been hypothesised in other cell types [3-7].

The question is whether in circulating lymphocytes PDH is responsive to insulin not only in vitro, but also in vivo. The assay of $\mathrm{PDH}$ activity in lymphocytes of patients with insulin dependent diabetes mellitus could prove helpful. For this reason, children with juvenile diabetes were examined at diagnosis and after insulin therapy.

\section{Subjects and Methods}

Enzymes, co-enzymes and substrates were supplied by Sigma Chemical Company (St.Louis, Mo, USA) and Biochemia Boehringer (Mannheim, FRG); Lymphoprep (density, 1.077) by Nyegaard \& Co., Oslo, Norway; porcine insulin $(40 \mathrm{U} / \mathrm{ml})$ by Lilly \& Co. (Indianapolis, Ind., USA); all the other products were analytical grade and were obtained from Merck (Darmstadt, FRG) and Carlo Erba (Milano, Italy). This study was performed in accordance with the principles of the Declaration of Helsinki and written informed consent was given by the parents of all children.

The experiments were carried out on 15 children ( 8 females and 7 males, aged $3-13$ years, mean age $9.87 \pm 3.2$ ) with newly diagnosed Type 1 (insulin-dependent) diabetes mellitus and on 15 subjects ( 9 fe- 
Table 1. Clinical data of the diabetic children at diagnosis

\begin{tabular}{llllll}
\hline $\begin{array}{l}\text { Diabetic } \\
\text { children } \\
\text { (number) }\end{array}$ & Arterial & $\begin{array}{l}\text { Blood } \\
\text { glucose } \\
(\mathrm{mmol} / \mathrm{l})\end{array}$ & $\begin{array}{l}\text { Urinary } \\
\text { glucose } \\
(\mathrm{g} / \mathrm{l})\end{array}$ & $\begin{array}{l}\text { Urinary } \\
\text { ketone } \\
\text { bodies }\end{array}$ & $\begin{array}{l}\text { Basal }^{\mathrm{a}} \\
\mathrm{C} \text { peptide } \\
(\mathrm{ng} / \mathrm{ml})\end{array}$ \\
\hline 1) & 7.31 & 20.8 & 7.0 & ++ & 1.1 \\
$2)$ & 7.27 & 19.0 & 6.5 & +++ & 0.6 \\
$3)$ & 7.26 & 17.3 & 18.0 & +++ & 0.7 \\
$4)$ & 7.17 & 38.0 & 72.2 & ++++ & 0.45 \\
$5)$ & 7.28 & 29.1 & 50.0 & Negative & 1.3 \\
$6)$ & 7.24 & 22.7 & 35.0 & ++++ & 1.0 \\
$7)$ & 7.30 & 26.1 & 5.0 & +++ & 0.8 \\
$8)$ & 7.29 & 15.2 & 30.0 & +++ & 0.9 \\
$9)$ & 7.24 & 17.6 & 8.0 & +++ & 0.9 \\
$10)$ & 7.10 & 38.4 & 54.0 & ++++ & 0.8 \\
$11)$ & 7.25 & 31.0 & 20.0 & +++ & 1.0 \\
$12)$ & 7.37 & 19.0 & 58.0 & ++ & 0.7 \\
$13)$ & 7.28 & 24.8 & 45.0 & +++ & 0.6 \\
$14)$ & 7.34 & 15.0 & 12.0 & + & 0.6 \\
$15)$ & 7.30 & 23.1 & 16.0 & ++ & 0.8 \\
\hline
\end{tabular}

a Normal range of basal C peptide $0.7-2.5 \mathrm{ng} / \mathrm{ml}$

males and 6 males, aged 4-14 years, mean age 9.2 \pm 2.1 ) who had been referred to our hospital for diseases other than diabetes. Glycaemia was one of the routine examinations programmed for their follow-up as out-patients; only subjects with normal blood glucose levels at follow-up were considered. Clinical data of the diabetic patients are shown in Table 1 . Blood samples for the evaluation of the activity of lymphocyte PDH were drawn at the moment of diagnosis, before starting insulin therapy; and also, but only in seven cases (cases no.5, $10-15$ in Table 1) after 5 days of insulin therapy, when metabolic control had normalised. Blood was collected in plastic vials containing $10 \%$ EDTA pH 7.4 and diluted $1: 1$ with $0.9 \% \mathrm{NaCl}$. Two parts of diluted uncoagulated blood, according to Boyüm [8], were carefully layered on one part of Lymphoprep (mixture of sodium metrizoate and ficoll, final density $1.077 \mathrm{~g} / \mathrm{ml}$ ), in unsiliconated polycarbonate tubes and centrifuged at $400 \times \mathrm{g}$ for $20 \mathrm{~min}$ at $20^{\circ} \mathrm{C}$. Lymphocytes were collected, at the interface between Lymphoprep and plasma, with an automatic pipette, diluted three times with $0.11 \mathrm{~mol} / \mathrm{l}$ $\mathrm{NaCl}-0.44 \mathrm{~mol} / 1$ phosphate buffer $\mathrm{pH} 7.4$ (buffer $\mathrm{A}$ ) and centrifuged at $400 \times \mathrm{g}$ for $10 \mathrm{~min}$ at $20^{\circ} \mathrm{C}$. The pellet, suspended in buffer $\mathrm{A}$, was added with 3 volumes of $\mathrm{H}_{2} \mathrm{O}$ to lyse contaminating red cells and exactly $90 \mathrm{~s}$ later with a volume of $0.62 \mathrm{~mol} / 1 \mathrm{NaCl}$ [9]. Cells were sedimented, rinsed three times with buffer $A$, suspended in buffer $A$ and at this step identified by morphological, biochemical and immunological techniques [10-12]. According to these methods, the cell suspension in all samples was represented by $89-93 \%$ lymphocytes; monocytes were no more than $0.2-1.5 \%$.

One part of the cell suspension was used immediately for insulin incubation, another part for lymphocyte counting; the remaining cells were kept in a freezer at $-40^{\circ} \mathrm{C}$ for no longer than 8 days and used for PDH activity assay.

\section{PDH activity assay}

The PDH behaviour was checked by measuring: (a) the activity of already active $\mathrm{PDH}$, also called basal activity of the $\mathrm{PDH}$ complex (PDHa); (b) the activity of the already active $\mathrm{PDH}+$ the activity of the inactive converted into the active PDH, defined total activity of the PDH complex (PDHt).

For the assay of PDHt, $50 \mu 1$ thawed cells were incubated at $37^{\circ} \mathrm{C}$ for $10 \mathrm{~min}$ with $10 \mathrm{mmol} / 1 \mathrm{MgCl}_{2}, 50 \mu \mathrm{mol} / 1 \mathrm{CaCl}_{2}, 0.5 \mu \mathrm{g}$ albumin buffered in $0.1 \mathrm{~mol} / 1$ Tris- $\mathrm{HCl} \mathrm{pH} 8$ in a final volume of $100 \mu \mathrm{l}$. The incubation was left to continue by adding the components of PDH activity assay $[2,7]$. For the PDHa-test in some cases, $50 \mu 1$ thawed cells added with $0.5 \mu \mathrm{g}$ albumin buffered in $0.1 \mathrm{~mol} / 1$ Tris- $\mathrm{HCl} \mathrm{pH} 8$ were immediately incubated with the PDH assay components, including in this case $20 \mathrm{mmol} / 1 \mathrm{NaF}$ and $0.1 \mathrm{mmol} / 1 \mathrm{MgCl}_{2}$; in other cases, they were incubated for $10 \mathrm{~min}$ at $37^{\circ} \mathrm{C}$ with $50 \mathrm{mmol} / 1 \mathrm{NaF}$ and with $0.5 \mu \mathrm{g}$ albumin buffered in $0.1 \mathrm{~mol} / 1 \mathrm{Tris}-\mathrm{HCl} \mathrm{pH} 8$ and then added with the PDH assay components supplemented with $0.1 \mathrm{mmol} / 1$ $\mathrm{MgCl}_{2}$.

\section{Insulin incubation}

The PDH responsiveness to insulin in vitro was checked using fresh intact lymphocytes, incubated (1) with insulin, (2) with a cell free preparation from fresh intact and treated with insulin lymphocytes of normal volunteers, as previously described [2].

1. Fresh intact lymphocytes from diabetic children in buffer $A$ $\left(2-3 \cdot 10^{6}\right.$ cells $\left.\cdot \mathrm{ml}\right)$ were incubated for $15 \mathrm{~min}$ at $37^{\circ} \mathrm{C}$ with or without insulin, in a medium containing in $100 \mu \mathrm{l}: 50 \mu \mathrm{mol} / \mathrm{I} \mathrm{MgCl}_{2}$, $50 \mu \mathrm{mol} / 1 \mathrm{CaCl}_{2}$ and $0.5 \mu \mathrm{g}$ albumin buffered in $80 \mathrm{mmol} / 1$ phosphate buffer $\mathrm{pH}$ 7.4. The reaction was stopped by adding $1 \mathrm{ml}$ buffer A; samples were centrifuged at $400 \times g$ for $10 \mathrm{~min}$ at $20^{\circ} \mathrm{C}$, rinsed and resuspended in medium $\mathrm{A}$, stored at $-40^{\circ} \mathrm{C}$ for no longer than 8 days and tested for the PDH activity.

2. A cell free preparation $(20 \mu \mathrm{l})$ from human circulating lymphocytes incubated with insulin, as previously described $[2,7]$ was combined with $80 \mu \mathrm{l}$ of a mixture consisting of frozen and thawed lymphocytes from diabetic children pre-incubated for $10 \mathrm{~min}$ at $37^{\circ} \mathrm{C}$ with $0.5 \mu \mathrm{g}$ albumin in $0.1 \mathrm{~mol} / 1$ Tris- $\mathrm{HCl} \mathrm{pH} 8$ and $50 \mathrm{mmol} / 1 \mathrm{NaF}$ (samples used for the assay of PDHa) or $10 \mathrm{mmol} / 1 \mathrm{MgCl}_{2}$ and $50 \mu \mathrm{mol} / 1 \mathrm{CaCl}_{2}$ (samples used for the assay of PDHt). After $15 \mathrm{~min}$ at $37^{\circ} \mathrm{C}$, the components for PDH activity assay were added, as previously described $[2,7]$.

\section{Lymphocyte-counting procedures}

The cell suspension in buffer $\mathrm{A}(5 \mu \mathrm{l})$ was treated with $105 \mu$ leucocyte-counting fluid (aqueous solution of $0.1 \%$ acetic acid and $0.1 \%$ methyl violet) which in $5 \mathrm{~min}$ lyses all erythrocytes, leaving lymphocytes intact. The lymphocytes were subsequently counted in a haemocytometer.

\section{Statistical analysis}

Student's $t$ test for paired or unpaired data, as appropriate for each case, was used as the statistical test of significance. $p<0.01$ was taken as the criterion of significance.

\section{Results}

Basal PDH activity (PDHa) is deeply decreased $(-49 \%)$ in circulating lymphocytes from children with diabetes at diagnosis, compared with that found in age matched children with normal blood glucose levels. Furthermore, pre-incubation of the same cells with $\mathrm{mmol} / 1 \mathrm{Mg}^{2+}$ and $\mu \mathrm{mol} / 1 \mathrm{Ca}^{2+}$ does not cause any stimulating effect, so that no difference between basal (PDHa) and cation dependent $\mathrm{PDH}$ activities (PDHt) is measurable. In lymphocytes from control samples pretreated with $\mathrm{Mg}^{2+}$ and $\mathrm{Ca}^{2+}$, the $\mathrm{PDH}$ activity is increased by $39 \%$ compared with the basal PDH activity (Table 2).

The above described picture of the PDH behaviour in diabetic children is completely reversed when the 


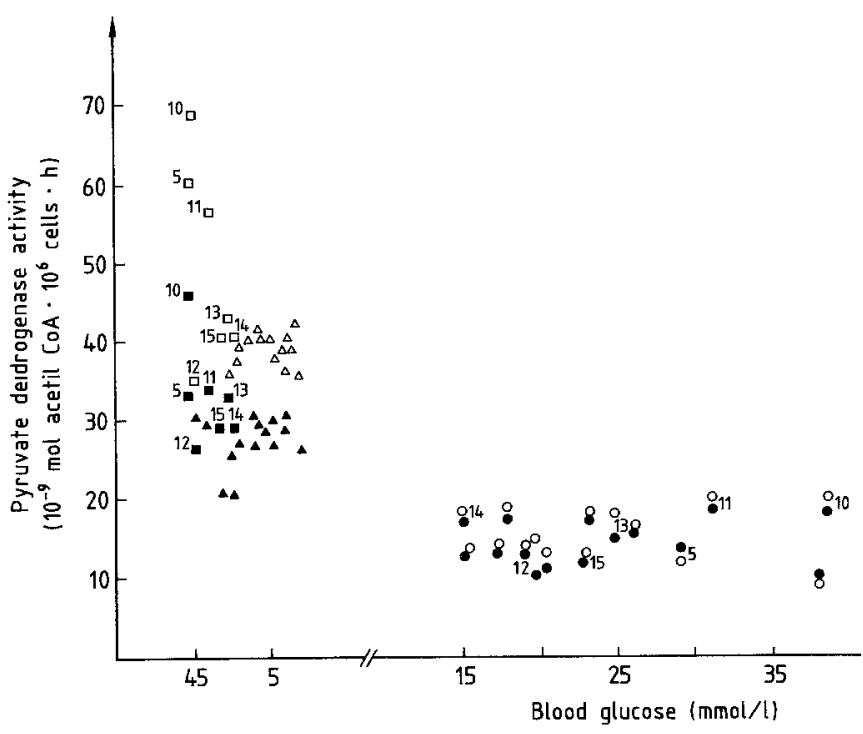

Fig. 1. Correlation between lymphocyte pyruvate dehydrogenase activity and blood glucose levels in diabetic, diabetic treated with insulin and normal children. Each point in the figure is the mean value of one independent experiment carried out in duplicate on one child. Normal children: PDHa $\triangle$ PDHt $\triangle$; Diabetic children: PDHa $\mathrm{PDHt} O$; Diabetic children treated with insulin (cases 5, 10-15): $\mathrm{PDHa}$ PDHt $\square . \mathrm{PDHa}=$ activity of active $\mathrm{PDH} ; \mathrm{PDHt}=$ total activity of the PDH complex

diabetic children are given rapid insulin $\left(1 \mathrm{U} \cdot \mathrm{kg}^{-1}\right.$. day $^{-1}$ ) for five days. The control of the PDH activity was carried out on blood samples drawn $12 \mathrm{~h}$ after the last insulin injection. In diabetic children treated with insulin, basal and cation dependent PDH activities, as in control subjects, reach different values (PDHa representing $66 \%$ of PDHt); both PDHa and PDHt attain similar or even higher levels than those of control subjects (Table 3 and Fig. 1).

In vitro, the combining of lymphocytes from diabetic children with insulin, or with a cell free preparation from lymphocytes of healthy donors, incubated with insulin (see Methods) modifies the PDH behaviour in a similar manner to that described in lymphocytes after in vivo insulin treatment; however, in both cases the responsiveness of PDH is less impressive if compared with in vivo insulin treatment (Table 4).

\section{Discussion}

In lymphocytes from diabetic children, the activity of the active PDH is deeply decreased, but the most impressive modification is the unresponsiveness of $\mathrm{PDH}$ to higher $\mathrm{Mg}^{2+}$ and $\mathrm{Ca}^{2+}$ concentration exposure, a situation which in lymphocytes from control subjects increases the PDH activity by about $39 \%$. As the cation effect on PDH mirrors the activity of PDHP phosphatase, it seems likely that a deficiency of insulin is responsible for an inactivation or a decreased level of PDHP phosphatase. A PDH behaviour very similar to that found in lymphocytes of diabetic children has also
Table 2. Pyruvate dehydrogenase activity in circulating lymphocytes from diabetic [15] and normal [15] children

\begin{tabular}{lll}
\hline Children & \multicolumn{2}{l}{ Pyruvate dehydrogenase activity } \\
\cline { 2 - 3 } & PDHa & PDHt \\
\hline Diabetic & $14.7 \pm 3.2^{\mathrm{a}}$ & $16.0 \pm 3.7^{\mathrm{b}}$ \\
Normal & $28.8 \pm 1.6^{\mathrm{a}^{\prime}}$ & $39.3 \pm 1.4^{\mathrm{b}^{\prime}}$ \\
\hline
\end{tabular}

$\mathrm{PDH}$ activity is expressed as nmoles acetylCoA $\cdot 10^{6}$ cells $\cdot \mathrm{h}$. Values are the mean ${ }^{+}-$SD. PDHa $=$activity of active PDH; PDHt $=$total activity of the PDH complex. Student's unpaired t test: $\mathrm{a} \rightarrow \mathrm{a}^{\prime}$ and $\mathrm{b} \rightarrow \mathrm{b}^{\prime}$ $p<0.0005$; Student's paired $\mathrm{t}$ test: $\mathrm{a}^{\prime} \rightarrow \mathrm{b}^{\prime} p<0.0005, \mathrm{a} \rightarrow \mathrm{b} p$ not significant

Table 3. Pyruvate dehydrogenase behaviour in circulating lymphocytes of diabetic children treated for 5 days with $1 \mathrm{U}$ insulin $\cdot \mathrm{Kg}^{-1}$. day $^{-1}$

\begin{tabular}{lll}
\hline Children & \multicolumn{2}{l}{ Pyruvate dehydrogenase activity } \\
\cline { 2 - 3 } & PDHa & PDHt \\
\hline Diabetic & $15 \pm 3.5^{\mathrm{a}}$ & $15 \pm 4.6^{\mathrm{b}}$ \\
Diabetic+Insulin & $34 \pm 7.2^{\mathrm{a}^{\mathrm{a}}}$ & $51 \pm 13.5^{\mathrm{b}^{\prime}}$ \\
\hline
\end{tabular}

$\mathrm{PDH}$ activity is expressed as nmoles acetyll $\mathrm{CoA} \cdot 10^{6}$ cells $\cdot h$. Values are the mean $\pm S D$ of duplicated independent experiments on 7 diabetic children before and after insulin treatment. PDHa $=$ activity of active PDH; PDHt $=$ total activity of the PDH complex. Student's paired $\mathrm{t}$ test $\mathrm{b} \rightarrow \mathrm{b}^{\prime}$ and $\mathrm{a}^{\prime} \rightarrow \mathrm{b}^{\prime} p<0.0025 ; \mathrm{a} \rightarrow \mathrm{a}^{\prime} p=0.005 ; \mathrm{a} \rightarrow \mathrm{b}$ $p$ not significant

Table 4. Pyruvate dehydrogenase behaviour in circulating lymphocytes of diabetic children incubated with insulin or with a cell free preparation from lymphocytes, added with exogenous insulin, of donors with normal blood glucose levels (see Methods)

\begin{tabular}{lll}
\hline Lymphocytes & \multicolumn{2}{l}{ Pyruvate dehydrogenase activity } \\
\cline { 2 - 3 } & PDHa & PDHt \\
\hline No additive & $15 \pm 3.0$ & $16 \pm 4.2$ \\
$\begin{array}{l}\text { With insulin } \\
\text { With a cell free preparation } \\
\text { from lymphocytes }\end{array}$ & $35 \pm 9.2$ & $45 \pm 11.7$ \\
incubated with insulin & $30 \pm 11.9$ & $40 \pm 14.3$ \\
\hline
\end{tabular}

PDH activity is expressed as nmoles acetylCoA $\cdot 10^{6}$ cells $\cdot h$. Values are the mean \pm SD of duplicated independent experiments on lymphocytes from 7 diabetic children. PDHa = activity of active PDH; $\mathrm{PDHt}=$ total activity of the PDH complex

been seen in different tissues of rats treated with alloxan or with streptozotocin [7, 13-15]. A role of acidosis and ketone bodies in the above mentioned PDH activity modifications is unlikely, since the results of various studies [2, 7, 13] indicate that: (a) the exposure of human circulating lymphocytes to different $\mathrm{pH}$ values, ranging between 6.5 and 8.0 , for $10 \mathrm{~min}$ at $37^{\circ} \mathrm{C}$, does not cause any modification of the PDH activity; (b) in brain homogenates and circulating lymphocytes of rats, $24 \mathrm{~h}$ after alloxan or streptozotocin administration, when glycosuria and glycaemia are already high, but ketone bodies are still in the normal range, the activity of the active PDH is already sharply inhibited and no conversion of the inactive into the active PDH is seen.

The PDH behaviour in lymphocytes of diabetic 
children is completely reversed after insulin therapy for 5 days. PDHa activity is increased, but more interesting $\mathrm{PDH}$ becomes again responsive to $\mathrm{Mg}^{2+}$ and $\mathrm{Ca}^{2+}$ exposure. The same PDH activity modifications are also seen after insulin combining with lymphocytes of diabetic patients in vitro; in this case, the degree of the $\mathrm{PDH}$ responsiveness is, however, less. The exact reason of this quantitative difference in the PDH stimulation is still unknown. The in vivo situation is much more complex than the in vitro one, where the only parameter involved is insulin. In vivo, it is likely that other hormones and/or environmental conditions can account for the greater PDH sensitivity. However, at this stage this is a minor point; the important point being that whether in vivo or in vitro $\mathrm{PDH}$ is sensitive to insulin. The increase of PDHa activity and the recovered responsiveness of $\mathrm{PDH}$ to $\mathrm{Mg}^{2+}$ and $\mathrm{Ca}^{2+}$ are in our opinion the expression of a stimulation of PDHP phosphatase and/or of a conformational modification of the phosphatase, which acquires much more affinity for the PDH complex so that exogenous $\mathrm{Ca}^{2+}$ and $\mathrm{Mg}^{2+}$ are no longer needed for the conversion of inactive pyruvate dehydrogenase (PDHi) into the active form (PDHa). So, in vivo and in vitro, the actual target for insulin is the PDHP phosphatase, and this is in agreement with the results obtained in untreated diabetic patients. Furthermore, it seems reasonable from the results of Table 4 , to suggest that the insulin modulation of PDH or of PDHP phosphatase takes place through the mediated mechanism already described in circulating lymphocytes from rats [7] and adult humans [2]. An insulin messenger(s), at least for the PDH complex, has been hypothesised also in other tissues $[3,5,6]$, but the structure of this mediator is still unidentified.

This study shows that whether in vivo or in vitro the PDH complex of circulating lymphocytes is sensitive to insulin. The intriguing question, for which further research is necessary, is if the PDH complex can be considered a specific, reliable and practical marker for insulin dependent diabetes; future studies should consider the lymphocyte PDH behaviour in insulin resistance, a prominent feature of obesity and insulin independent diabetes mellitus. From a different point of view the breakdown of the PDH activity levels could have a number of metabolic consequences. Glucose and aminoacids are very important in the provision of energy in circulating lymphocytes; since PDH is the key enzyme which controls the access of glucose and aminoacids, via pyruvate, to the Krebs cycle, a fall of its activity means a decrease of the Krebs cycle rate and energy supply, which in the case of lymphocytes might explain the breakdown of immunological reactions in diabetic patients.

Acknowledgements. The authors wish to thank Prof. F. Caligaris Cappio (Dipartimento di Scienze Biomediche ed Oncologia Umana) for his excellent technical assistance. This work was supported by the grant $\mathrm{N}^{\circ} 860055404$ of the Italian National Research Council.

\section{References}

1. Wieland $\mathrm{OH}$ (1983) The mammalian pyruvate dehydrogenase complex: Structure and regulation. Rev Physiol Biochem Pharmacol 96: $123-170$

2. Curto M, Piccinini M, Bruno R, Mostert M, Rinaudo MT (1988) Insulin modulation of pyruvate dehydrogenase in human circulating lymphocytes. Int J Biochem 20: 1211-1217

3. Larner J, Cheng K, Scharwtz C, Kikuchi K, Tamura S, Creacy S, Dubler R, Galasko G, Pullin C, Katz M (1982) Insulin mediators and their control of metabolism through protein phosphorylation. Recent Prog Horm Res 38: 511-552

4. Rinaudo MT, Curto M, Bruno R (1986) Effect of insulin on pyruvate dehydrogenase in a mixture of plasma membranes and mitocondria from normal and alloxan treated rat brains. Int $J$ Biochem 18: $603-607$

5. Rinaudo MT, Bedino S, Curto M, Testore G, Bruno R (1986) Characterization of a pyruvate dehydrogenase modulator purified from insulin treated rat brain plasma membranes. It J Biochem 35: 242-258

6. Rinaudo MT, Curto M, Bruno R, Marino C, Rossetti V, Mostert $M$ (1987) Evidence of an insulin generated pyruvate dehydrogenase stimulating factor in rat brain plasma membranes. Int $J$ Biochem 19: 909-913

7. Rinaudo MT, Curto M, Bruno R, Marino C, Mostert M (1988) Effects of insulin on pyruvate dehydrogenase in circulating lymphocytes from normal and diabetic rats. Int J Biochem 20: 667-674

8. Boyüm A (1968) Separation of leucocytes from blood and bone marrow. Scand J Clin Lab Invest 21:9-89

9. Blass JP, Avigan J, Uhlendorf BW (1970) A defect in pyruvate decarboxylase in a child with an intermittent movement disorder. $J$ Clin Invest 49: 423-432

10. Janossy G, Bollum FJ, Bradstock KF, Ashley J (1980) Cellular phenotypes of normal and leukemic hemopoietic cells determined by analysis with selected monoclonal antibody combinations. Blood 56: 430-441

11. Lennert K, Mohri N, Stein H, Kaiserling E, Müller-Hermelink HK (1978) Malignant lymphomas other than Hodgkin's disease. In: Lennert $\mathrm{K}$ (ed) Handbuch der Speziellen Pathologischen Anatomie und Histologie, Bd 1, Teil 3B. Springer, Berlin Heidelberg New York, pp 9-19

12. Mueller J, Brun Del Re G, Buerki H, Keller HU, Hess MW, Cottier $H$ (1975) Non specific esters activity: a criterion for differentiation of $\mathrm{T}$ and $\mathrm{B}$ lymphocytes in mouse lymph-nodes. Eur J Immunol 5: 270-27.4

13. Rinaudo MT, Curto M, Bruno R (1985) Effect of insulin on pyruvate dehydrogenase complex in the rat brain. It $\mathrm{J}$ Biochem 34: 229-237

14. Wieland $\mathrm{OH}$, Siess E, Schulze-Wethmar FH, Von Funcke $\mathrm{HG}$, Winton B (1971) Active and inactive forms of pyruvate dehydrogenase in rat heart and kidney. Effect of diabetes, fasting and refeeding on pyruvate dehydrogenase interconversion. Arch Biochem Biophys 143: 593-601

15. Wieland OH, Siess EA, Weiss L, Löffler G, Patzelt C, Portenhauser R, Hartmann V, Schirmann A (1973) Regulation of mammalian pyruvate dehydrogenase complex by covalent modifications. Symp Soc Exp Biol 27:371-400

Received: 14 September 1988

and in revised form: 16 February 1989

Prof. M.T. Rinaudo

Dipartimento di Medicina ed Oncologia Sperimentale

Sezione Biochimica

Via Michelangelo 27

I-10126 Torino

Italy 